\title{
Aeration of the root system in Alnus glutinosa L. Gaertn.
}

\author{
P. Schröder
}

Bot. Inst. Univ. Cologne, Gyrhofstr. 15, D-5000 Köln 41, F.R.G.

\section{Introduction and theoretical considera- tions}

When soils are wet or flooded during winter or spring, many plants suffer from persistent anoxia of their rhizospheres. Oxygen diffusion from the atmosphere through the wet soil is insufficient to overcome this $\mathrm{O}_{2}$ deficiency because of the low solubility and the low diffusion velocity of $\mathrm{O}_{2}$ in the aqueous phase. Thus it is obvious that the only plants that can survive in temporarily flooded ecosystems are those that have developed the ability to tolerate or to avoid root anoxia for longer periods of time.

As has been recently shown (Grosse and Schröder, $1984 ; 1985 ; 1986)$, the wetland alder Alnus glutinosa L. Gaertn. is able to improve $\mathrm{O}_{2}$-supply to its root system by gas transport from the aerial parts of its stem to the roots. The gas transport in $A$. glutinosa is assumed to be thermoosmotic. Thermo-osmosis of gases is a physicochemical effect based on Knudsen-diffusion (Takaishi and Sensui, 1963) found in several plants living in wet habitats (Grosse and Schröder, 1986; Schrö- der et al., 1986; Grosse and Mevi-Schütz, 1987).

Thermo-osmosis might generally be described as any flow of matter between two compartments under the influence of a temperature gradient through a membrane with pores in the range of the mean free path lengths of the gas molecules considered (Knudsen, 1910; Denbigh and Raumann, 1952; Takaishi and Sensui, 1963). The mean free path length is defined as the average distance the gas molecules cover between successive collisions. For air molecules moving statistically with speeds according to Maxwell's law, the mean free path length is $0.1 \mu \mathrm{m}$. Due to the laws of Knudsen-diffusion (restricted diffusion), gas flow is always directed towards the warmer compartment; a rise in gas pressure results in this compartment. Experiments showed that thermoosmotic pressurization is even possible with pores of $1-1.5 \mu \mathrm{m}$ in diameter (Takaishi and Sensui, 1963).

The stem is assumed to be the thermoosmotic chamber in A. glutinosa, with the lenticel tissue acting as a fine porous

\footnotetext{
* Present address: Fraunhofer Institute f. Atmospheric Environmental Research, Kreuzeckbahnstr. 19, D-8100 Garmisch-Partenkirchen, F.R.G.
} 
membrane between the atmosphere and the intercellular system inside. Intercellular spaces $1-5 \mu \mathrm{m}$ in diameter are frequently found in the lenticel tissue of young leafless alders (Köstler et al., 1968). When there is a temperature difference between the stem and the surrounding air, the gas inside the stem will be pressurized and flow through the intercellular spaces of the phloem and the xylem to the roots.

\section{Materials and Methods}

Experiments were carried out with 6 mo old seedlings of different deciduous tree species. Temperature differences between the stems and the atmosphere were measured as previously described (Grosse and Schröder, 1984; 1985 ; 1986). Gas diffusion and transport through young trees were measured by a tracer gas technique. $11 \%(\mathrm{v} / \mathrm{v})$ ethane was injected into the middle chamber of a glass apparatus containing the stem of a young leafless tree. The tracer gas flow out of the stems into an upper chamber as well as out of the roots into a lower chamber was recorded by FID-GC. $\mathrm{O}_{2}$ escape out of the roots of alders was measured by means of a Clark type $\mathrm{O}_{2}$ electrode (Bachofer, F.R.G.).

\section{Description of FID-GC}

Hewlett-Packard $5750 \mathrm{GC}$ with flame ionization detector, equipped with 1/8" column Porapak $P / Q, 3 \mathrm{ft}$ each, $65^{\circ} \mathrm{C}$, flow rates :

Table I. Light-induced temperature differences $(\delta T)$ between atmosphere $\left(T_{\mathrm{a}}\right)$ and the stems $\left(T_{i}\right)$ of 6 mo old trees.

\begin{tabular}{lll}
\hline Species & $\begin{array}{l}\text { Light intensity } \\
\left(\mu \mathrm{mol} \cdot \mathrm{m}^{-2} \cdot \mathrm{sec}^{-1}\right)\end{array}$ \\
\cline { 2 - 3 } & $\begin{array}{c}100 \\
\left(\delta \mathrm{T}=\mathrm{T}_{\mathrm{i}}-\mathrm{T}_{\mathrm{a}}[\mathrm{K}]\right)\end{array}$ \\
\hline Acer pseudoplatanus & $1.6 \pm 0.3$ & $3.8 \pm 0.3$ \\
Aesculus hippocastanum & $1.8 \pm 0.3$ & $3.5 \pm 0.7$ \\
Alnus glutinosa & $1.9 \pm 0.3$ & $3.6 \pm 0.3$ \\
Alnus incana & $1.7 \pm 0.5$ & $3.6 \pm 0.3$ \\
Carpinus betulus & $2.1 \pm 0.6$ & $3.4 \pm 0.3$ \\
Fagus sylvatica & $2.2 \pm 0.3$ & $3.9 \pm 0.5$ \\
Fraxinus excelsior & $1.4 \pm 3.0$ & $3.0 \pm 0.6$ \\
\hline
\end{tabular}

$\mathrm{N}_{2}: 60 \mathrm{ml} \cdot \mathrm{min}^{-1}, \mathrm{H}_{2}: 30 \mathrm{ml} \cdot \mathrm{min}^{-1}$, synth. air: $300 \mathrm{ml}^{\circ} \mathrm{min}^{-1}$.

\section{Results}

Temperature differences of $2-10^{\circ} \mathrm{K}$ between the bark of young trees and the atmosphere can be measured whenever

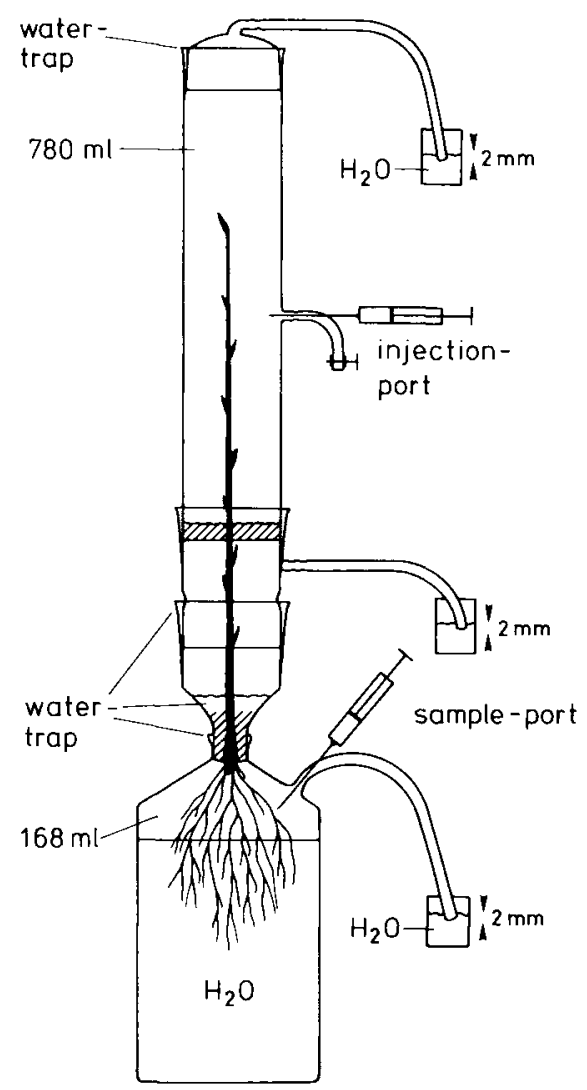

Fig. 1. Tracer gas studies with 6 mo old leafless trees were conducted to characterize gas flow to the upper parts of the stems and to the roots of young deciduous trees. The figure shows a glass apparatus constructed for this purpose. It consists of 3 gas-tight vessels completely separated from each other. Tracer gas is injected into the middle compartment of the apparatus. Gas molecules have to pass through the plant in order to escape out of the roots or stems. The root containing chamber was kept dark during all experiments, the upper parts of the apparatus were illuminated during light experiments. 

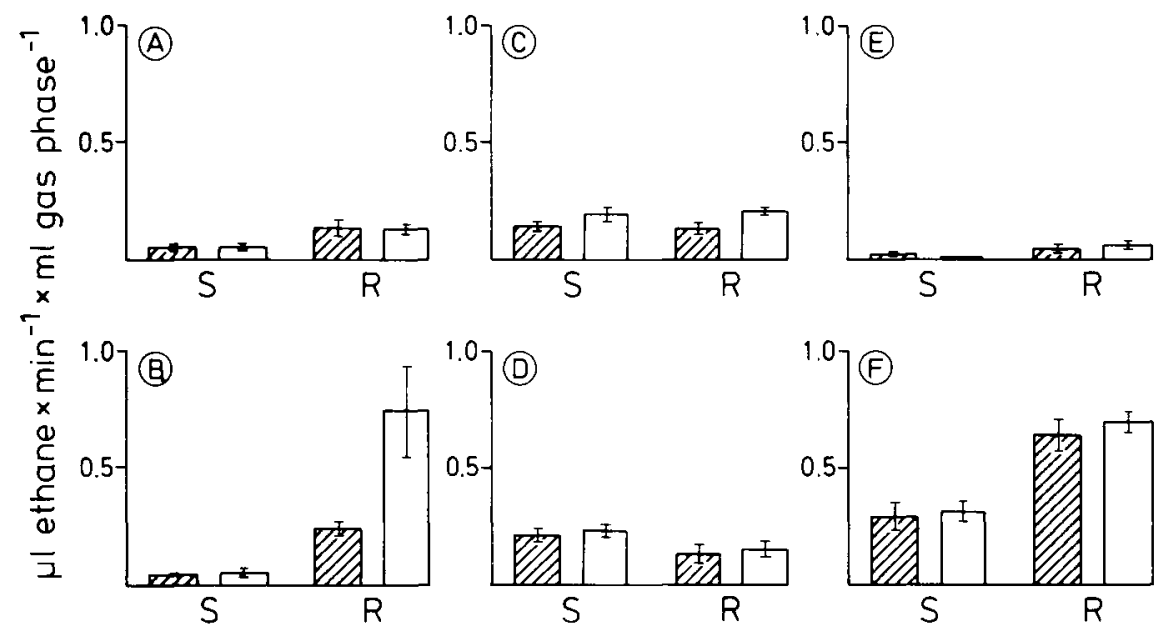

Fig. 2. Results of the tracer gas experiments with ethane (11.4\% in air, v/v) in the glass apparatus. (A) Acer pseudoplatanus, (B) Alnus glutinosa, (C) Alnus incana, (D) Carpinus betulus, (E) Fagus sylvatica, (F) Fraxinus excelsior. First bars show the gas flow to the stem (S), last bars show gas flow to the roots (R). Hatched bars are for dark, white bars for light experiments $(n=9 \pm$ SD)

the stems are irradiated by an artificial light source or the sun (Table I). The temperature differences established due to irradiation are similar in all investigated tree species. A. glutinosa is the only tree in which, correlated to this rise in temperature, small pressure differences between stem and atmosphere can be recorded (Schröder, 1986). This should, according to the theory, lead to an enhanced gas transport to the roots.

Gas flow to the stems and roots was studied in experiments with 6 deciduous tree species, using ethane as a tracer gas. A sketch of the apparatus used for the experiments is shown in Fig. 1.

The graphs (Fig. 2) show results of the tracer measurements. Gas flow through the stems to root and shoot can be observed in each of the investigated species. In most species, gas flow to the roots was dominant. In $A$. incana and in $C$. betulus $(2 C, D)$, roots and stems were supplied with air at equal rates, whereas in $A$. pseudoplatanu's and in A. glutinosa (2A, $B)$, gas diffusion to the stem was negligible and most of the gas escaped out of the roots. Almost no gas flow could be observed in F. sylvatica (2E). Diffusion rates in $F$. excelsior were extremely high to the stem, but twice as much gas reached the roots (Fig. $2 \mathrm{~F}$ ). A. glutinosa and $A$. incana $(2 \mathrm{~B}, \mathrm{C})$ were the only trees showing any significant enhancement of gas flow to the roots or the stems after irradiation.

A series of experiments with 6 and 12 mo old leaf-covered and leafless alder trees was conducted to examine oxygen escape out of the roots in the dark at $20^{\circ} \mathrm{C}$ (a) and $5^{\circ} \mathrm{C}$ for leafless (b) and leaf-covered alders (c), respectively (Fig. 3). Oxygen diffusion down to the roots was not sufficient to fulfill respiratory demands of the trees. Irradiation of the stem led to increased gas transport and to oxidation of the rhizosphere (cross-hatched bars). 


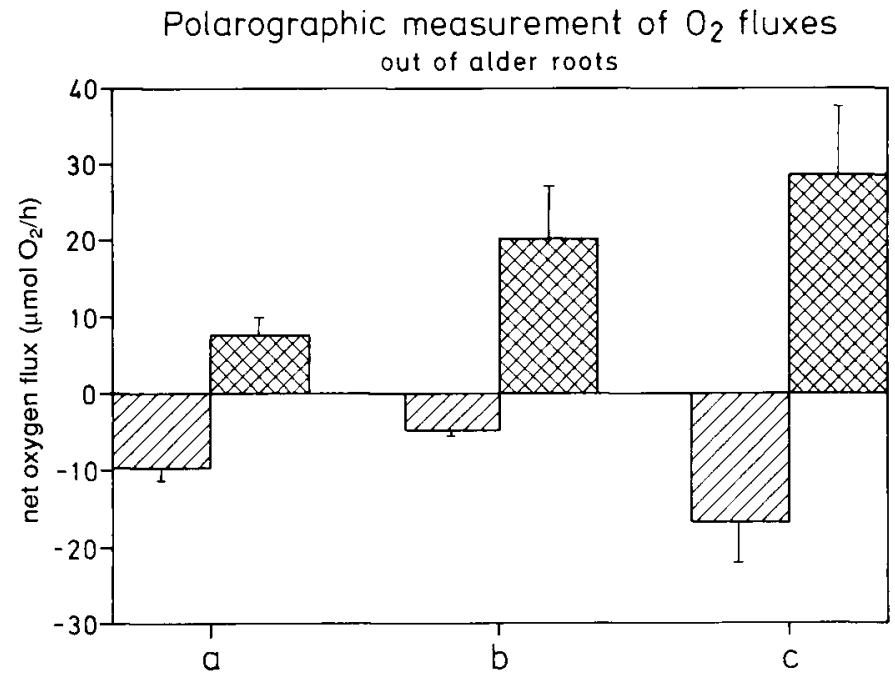

Fig. 3. Measurements with an oxygen electrode in leafless $(\mathbf{a}, \mathbf{b})$ and leaf-covered $(\mathbf{c})$ alder trees. Hatched bars are for dark experiments, cross-hatched bars for light experiments. Values are corrected for the different root temperatures $(n=16 \pm \mathrm{SE})$.

\section{Discussion and Conclusions}

Although all investigated tree species showed significant rises in stem temperature upon irradiation, $A$. glutinosa was the only one which developed small pressure differences inside its stem. This may, according to the theory, be due to the existence of small intercellular spaces inside the lenticel tissue stimulating thermo-osmosis of gases. In A. incana, measurements of pressure differences showed no significant results; it has to be assumed that pressure differences occur in a range too small to be measured with the equipment available. Tracer gas experiments with young leafless trees were conducted to clarify the thermo-osmotic phenomenon. Except for $C$. betulus, gas diffusion rates during dark experiments were always higher to the roots than to the stems. This might be due to the fact that in many trees root tissue is more porous than the upper parts of the stem (Köstler et al., 1968). F. sylvatica seems to be nearly impermeable to gases. In $F$. exce/sior, gas flow rates due to diffusion were the highest; diffusion towards the roots was twice as high as diffusion to the stem. No enhancement of gas flow could be induced by irradiating the stem. Obviously, there are no thermo-osmotically active tissues in $F$. excelsior. A. pseudoplatanus had diffusion rates similar to those of Alnus species, but an enhanced air flow to the upper parts of the stems and the roots due to a thermo-osmotically mediated gas transport could only be demonstrated in A. glutinosa. The amounts of gas transported into the stems and roots at $200 \mu \mathrm{E} \cdot \mathrm{m}^{-2} \cdot \mathrm{s}^{-1}$ and a $\delta T$ of $2^{\circ} \mathrm{K}$ between stem and atmosphere were 2-4 times higher than the diffusion rates in the dark at $\delta T=0$. Due to this adaptation, $A$. glutinosa reached gas flow rates even higher than those of $F$. excelsior, which is known 
to stand flooding for longer periods of time. Almost no gas transport could be shown in $A$. incana, which is a closely related tree, that always grows in drained soil.

Experiments with a Clark-type $\mathrm{O}_{2}$ electrode confirmed that thermo-osmotic gas transport leads to an increase of the $\mathrm{O}_{2}$ concentration in the rhizosphere of $A$. glutinosa. Oxygen diffusion through the stem is not sufficient to satisfy the $\mathrm{O}_{2}$ demand of the roots in leafless and leaf-covered young alders. Thermo-osmotic gas transport enhances the $\mathrm{O}_{2}$ flow to rates sufficient to guarantee respiration and oxidizes the rhizosphere with up to $7.8 \mu 1 \mathrm{O}_{2} \cdot \mathrm{min}^{-1}$ in leafless trees and $11 \mu \mathrm{IO}_{2} \cdot \mathrm{min}^{-1}$ in leafcovered trees, respectively. The oxidation of the rhizosphere might be very important to alder's roots and inhibit growth of bacteria or accumulation of toxic compounds close to the roots.

Thermo-osmotic gas transport must be seen as a special adaptation in plant species living in anaerobic environments with considerable ecological importance for $A$. glutinosa. Further investigations with tracer gases and polarographic techniques are necessary to clarify the phenomenon of thermo-osmosis and its occurrence in flood-tolerant tree species.

\section{Acknowledgments}

The author wishes to thank Dr. W. Grosse, University of Cologne, for providing working space in his laboratory and for critical and helpful discussions. Financial support from the DFG is gratefully acknowledged.

\section{References}

Denbigh K.G. \& Raumann G. (1952) The thermo-osmosis of gases through a membrane. Proc. R. Soc. London 210A, 377-387

Grosse W. \& Mevi-Schütz J. (1987) A beneficial gas transport system in Nymphoides peltata. Am. J. Bot. 47, 941-952

Grosse W. \& Schröder P. (1984) Oxygen supply of roots by gas transport in alder trees. $Z$. Naturforsch 39c, 1186-1188

Grosse W. \& Schröder P. (1985) Aeration of the roots and chloroplast-free tissues of trees. Ber. Dtsch. Bot. Ges. 98, 311-318

Grosse W. \& Schröder P. (1986) Plant life under anaerobic conditions. A review. Ber. Dtsch. Bot. Ges. 99, 367-381

Knudsen M. (1910) Eine revision der gleichgewichtbedingungen der gase. Thermische molekularströmung. Ann. Phys. 31, 205-229

Köstler J.N., Bruckner F. \& Bibelriether $H$. (1968) In: Die Wurzeln der Waldbäume. Parey Publ., Hamburg

Schröder P. (1986) Thermo-osmotischer sauerstofftransport in Alnus glutinosa und Nuphar lutea als anpassung an ein leben in anaerober umgebung. Ph.D. Thesis, University of Cologne, F.R.G.

Schröder P., Grosse W. \& Woermann D. (1986) Localization of thermo-osmotically active partitions of Nuphar lutea. J. Exp. Bot. 37, 14501461

Takaishi T. \& Sensui Y. (1963) Thermal transpiration effect of hydrogen, rare gases, and methane. Trans. Faraday Soc. 59, 2503-2514 